\title{
Structuring of a Haplortox by Soil Cover Species
}

\author{
Luciene Kazue Tokura ${ }^{1}$, Deonir Secco ${ }^{1}$, Luiz Antônio Zanão Júnior ${ }^{2}$, Jair Antonio Cruz Siqueira ${ }^{1}$, \\ Samuel Nelson Melegari de Souza ${ }^{1}$, Reinaldo Aparecido Baricatti ${ }^{1}$, Alessandra Mayumi Tokura Alovisi ${ }^{3}$, \\ Andersson Barison ${ }^{4}$, Bruna de Villa ${ }^{1}$, Maurício Antônio Pilatti ${ }^{1}$, Katlin Suellen Rech ${ }^{4}$ \& Romeu Reginatto ${ }^{5}$ \\ ${ }^{1}$ Pós-Graduation Program, Master's in Engineering of Energy in Agriculture, State University of West Paraná, \\ Cascavel, Paraná, Brazil \\ ${ }^{2}$ Agronomic Institute of Paraná, Santa Tereza do Oeste, Paraná, Brazil \\ ${ }^{3}$ Post-Graduation Program in Agronomy, Universidade Federal da Grande Dourados, Dourados, Mato Grosso do \\ Sul, Brazil \\ ${ }^{4}$ NMR Center, Federal University of Paraná, Curitiba, Paraná, Brazil \\ ${ }^{5}$ State University of West Paraná, Foz do Iguaçu, Paraná, Brazil \\ Correspondence: Luciene Kazue Tokura, Pós-Graduation Program, Master's in Engineering of Energy in \\ Agriculture, State University of West Paraná, Rua Universitária, 2069, Jardim Universitário, Brazil. Tel: \\ 55-(45)-3220-3151. E-mail: lucienetokura@gmail.com
}

Received: December 12, 2017 Accepted: February 13, $2018 \quad$ Online Published: October 15, 2018

doi:10.5539/jas.v10n11p299 URL: https://doi.org/10.5539/jas.v10n11p299

\begin{abstract}
The objective of this work was to evaluate the effect of soil cover species and management systems in improving the physical characteristics of a Haplortox and its effects on grain yield and soybean oil content. The experimental area, consisted of 15 treatments in a completely randomized experimental design. Each plot had size of $20 \times 25$ $\mathrm{m}$. The treatments consisted of: traditional no-tillage system (control), no-tillage system with application of gypsum, no-tillage with scarification and 12 treatments with cover species called soil structure reclaimers. Soil samples were collected in the layers of $0-0.10 ; 0.10-0.20$ and $0.20-0.30 \mathrm{~m}$, with four replicates. The physical attributes evaluated were bulk density, total porosity, microporosity, macroporosity and saturated hydraulic conductivity in the periods of 2014, 2015 and 2016. In the soybean crop the grain yield, oil content, weight of 100 grains, average height of plants and number of plants $/ \mathrm{m}$ were evaluated in each treatment with four replications. The oil content was performed by the low-field nuclear magnetic resonance method. The averages of the treatments were compared by the Tukey test at $5 \%$ of significance. The results showed that five months after soil scarification did not affect bulk density. Eleven months after gypsum application discrete improvements in density, total porosity, microporosity and soil hydraulic conductivity occurred in the $0-0.10$ and 0.10-0.20 m layers. It was also concluded that grain yield, oil content, weight of 100 grains and number of plants per meter were not influenced by the soil cover species and soil management systems.
\end{abstract}

Keywords: vegetation cover, management systems, productivity, oleaginous

\section{Introduction}

To the system of no-tillage, characteristics of minimal mobilization are attributed to the soil constituents, which are essential to the plants development, supporting root growth, providing water, oxygen, nutrients (Amaral et al., 2004; Pereira et al., 2010) and soil surface protection (Bertin, Andioli, \& Centurion, 2005).

The maintenance of cover species on the soil surface provides a continuous supply of plant residues, and can occur to the improvement of some physical attributes, such as soil structuring, porosity, water infiltration and retention, permeability, among others (Bertol et al., 2004).

Among the improvements in the physical attributes of the soil, the structure can be regarded as the most important under the agricultural point of view, because it is attributed fundamental properties in soil-plant relationships (Torres et al., 2013).

However, when this system is conducted without crop rotation and the farmer uses intensive traffic of machines and equipment, in most of the times without taking into account the soil moisture conditions, soil subsurface compaction occurs. Soil moisture is one of the determinants factors of soil susceptibility to compaction, 
especially in Haplortox. Such changes in soil physical attributes lead to a reduction in soil oxygen diffusion rates and high resistance to root penetration, contributing to low crop development and, at the same time, causing damage to farmers (Silva, Reinert, \& Reichert, 2000; Silva et al., 2002; Secco et al., 2004; Braida et al., 2006; Servadio, Bergonzoli, \& Toderi, 2014; Servadio, Bergonzoli, \& Beni, 2016).

For the good development of crops, the soil must perform its functions perfectly. The no-tillage system when managed in an incorrect way increases the bulk density, due to compaction. For Hamza and Anderson (2005), and Servadio (2010) the excessive use of machines, monoculture, short period with crop rotation and inadequate soil management can lead to compaction. One of the mechanical means to eliminate compaction is scarification (Gabriel Filho et al., 2000), but this process, although breaking compacted layers when performed properly, makes the soil susceptible to new compacting and erosion (Tormena et al., 2002).

Another method that can promote the non-compaction of the soil is the use of soil cover species, denominated soil structure reclaimers. These species present root development capable of developing in soils with high resistance to penetration, aiding in the cycling of nutrients and bringing the leached nutrients to the surface. In addition, the use of cover crops aims to protect the soil against erosion, to maintain greater amount of organic matter in the soil and to alleviate the effects of compaction by leaving stable biopores where the roots of successor crops can use these to grow more deeply (Balesdent, Chenu, \& Balabane, 2000; Oliveira et al., 2011; Crusciol et al., 2012; Ferrari Neto et al., 2012; Nascente \& Crusciol, 2012).

Soil non-compaction by this method is a strategy to increase water availability for the plants at times of rain restriction. Thus, the successor crop will exploit a larger volume of soil and, consequently, will have a greater availability of water. For Bublitz (2014), in the State of Paraná, 91.65\% of the area available for sowing is conducted under no-tillage system. The successor crops implanted in these areas correspond to soybean, corn and bean crops.

Studies on summer and winter cover species in different soil management systems are necessary to have a diversity of species capable of producing different amounts of plant residues that, when decomposing, positively alter physical and chemical attributes, and consequently the productivity of the successor culture. In this way, the objective of the present work was to evaluate the effect of different soil management systems and vegetation cover species on the soil structure, grain yielding and soybean oil content.

\section{Material and Methods}

\subsection{Location and Characterization of the Experimental Area}

The work was performed at the experimental station from the Agronomic Institute of Parana (IAPAR), in Santa

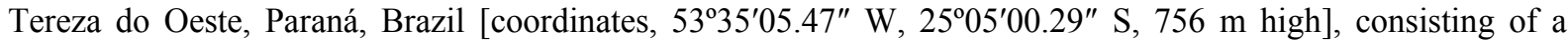
Harplortox of clay texture soil (EMBRAPA, 2013). According to Köppen (Cfa), the climate of the region is classified as humid subtropical, with average annual precipitation of 1800-2000 mm (IAPAR, 2000).

The experiment was performed from March 2014 to February 2016; using summer and winter cover species, followed by the soybean crop (2014/2015/2016 harvest). The last liming application was done in 2011 with $3 \mathrm{Mg}$ ha ${ }^{-1}$ of limestone.

Before (2014) and after (2016) field tests starts the follows soil physical properties: bulk density (BD), total porosity (TP), micro (Micro) and macroporosity (Macro) were evaluated in the layers of 0-0.10; 0.10-0.20 and 0.20-0.30 m deep, according to the methodology described in Embrapa's manual of physical analysis methods (1997) and saturated hydraulic conductivity $\left(\mathrm{K}_{\theta \mathrm{S}}\right)$, according to Reinert and Reichert (2006).

This area has been used for no-tillage system by 19 years with the following crop sequences: maize/black oats for forage (2011/2012 harvest), beans and soybeans/wheat and black oats (2012/2013 harvest), and soybean (2013/2014 harvest).

\subsection{Characterization and Management of the Treatments}

The experiment consisted of 15 treatments, in a completely randomized design. 12 treatments, six of summer and six of winter plant cover crops were used and in three treatments with different management systems (no-tillage, scarified tillage and traditional tillage, the latter used as control). Those performed with summer crops were of pearl millet (Pennisetum americanum (L.) Leeke), dwarf pigeon pea (Cajanus cajan) IAPAR 43-Aratã, sunn hemp (Crotalaria juncea (L.)), pigeon pea (Cajanus cajan (L.) Millsp.), rattlebox (Crotalaria spectabilis Roth) and velvet bean (Mucuna pruriens (L.) DC.). While those performed in winter time used white oats (Avena sativa $\mathrm{L}$.) UPFA gauderia, black oats (Avena strigosa Schreb.) IPR Cabocla, cereal rye (Secale cereale L.) IPR 89, black oats 
+ cultivated radish (Raphanus sativus L.) IPR 116 association, black oat + white lupine association (Lupinus albus L.) and black oat + garden pea (Pisum arvense L.) IAPAR 83 association.

The no-tillage system consisted of the application of $3 \mathrm{Mg} \mathrm{ha}^{-1}$ of gypsum on the surface. In the no-tillage system with scarification, the scarification was up to $0.30 \mathrm{~m}$ deep. Each treatment had an area of $500 \mathrm{~m}^{2}(20 \times 25 \mathrm{~m})$.

The summer cover species were deployed in March 27, 2014. The cover of pearl millet $\left(15 \mathrm{~kg} \mathrm{ha}^{-1}\right)$, sunn hemp (25 $\left.\mathrm{kg} \mathrm{ha}^{-1}\right)$, rattlebox $\left(15 \mathrm{~kg} \mathrm{ha}^{-1}\right)$ were sown with spacing of $0.17 \mathrm{~m}$; dwarf pigeon pea $\left(30 \mathrm{~kg} \mathrm{ha}^{-1}\right)$, pigeon pea $(50 \mathrm{~kg}$ $\left.\mathrm{ha}^{-1}\right)$, with spacing of $0.34 \mathrm{~m}$ and velvet bean $\left(70 \mathrm{~kg} \mathrm{ha}^{-1}\right)$, with spacing of $0.45 \mathrm{~m}$, without fertilization. On March 31,2015 , the cover species were repeated in the same portions of the previous year.

The winter cover was sown on July 17,2014 , with common oat $\left(70 \mathrm{~kg} \mathrm{ha}^{-1}\right)$, black oat $\left(40 \mathrm{~kg} \mathrm{ha}^{-1}\right)$, cereal rye (70 $\left.\mathrm{kg} \mathrm{ha}^{-1}\right)$, black oat + cultivated radish $\left(40 \mathrm{~kg} \mathrm{ha}^{-1}+4 \mathrm{~kg} \mathrm{ha}^{-1}\right)$, black oat + white lupine $\left(40 \mathrm{~kg} \mathrm{ha}^{-1}+90 \mathrm{~kg} \mathrm{ha}^{-1}\right)$ and black oat + garden pea $\left(40 \mathrm{~kg} \mathrm{ha}^{-1}+30 \mathrm{~kg} \mathrm{ha}^{-1}\right)$, spacing of $0.34 \mathrm{~m}$, without fertilization. On March 31, 2015, these six treatments were planted with crambe (Crambe abyssinica Hochst) $\left(12 \mathrm{~kg} \mathrm{ha}^{-1}\right)$ FMS hybrid bright, using seeder with six lines with spacing of $0.34 \mathrm{~m}$, without fertilization.

The desiccation of the vegetation cover species of summer and winter occurred in flowering time with original glyphosate application $\left(4 \mathrm{~L} \mathrm{ha}^{-1}\right)$. Subsequently, triton was used so that plant residues were evenly distributed in the area.

The scarification was conducted in the area up to $0.30 \mathrm{~m}$ deep using a cutting blade scarifier $0.50 \mathrm{~m}$ spaced at October 20, 2014.

The system with gypsum application was performed on April 10, 2014, with application of $3 \mathrm{Mg} \mathrm{ha}^{-1}$ on the surface of the experimental area.

\subsection{Evaluation of Soybean Plants}

Soybean sowing (Glycine $\max$ (L.) Merrill) was carried on the vegetal remains of the soil cover species, on November 11, 2014 (2014/2015 harvest), and on October 20, 2015 (2015/2016 harvest). The cultivar used was NA5909 RG, $0.45 \mathrm{~m}$ spaced, 16 seeds per meter, and fertilization of $300 \mathrm{~kg} \mathrm{ha}^{-1}$ of the NPK formulation 2-20-18.

Cultural practices for the control of weeds, pests and diseases were carried out in the according to technical recommendations for soybean culture.

The soybean harvest was performed on March 10, 2015 (2014/2015 harvest), and February 29, 2016 (2015/2016 harvest). The grain yielding was evaluated in central areas of $8.1 \mathrm{~m}^{2}$, constituting 3 lines of $6.0 \mathrm{~m}$, with spacing of $0.45 \mathrm{~m}$ between lines, with four replications per plot. Subsequently, the removal of impurities and cleaning of the seeds.

Soybean grain yield was obtained by weight from each subplot and transformed in $\mathrm{kg} \mathrm{ha}^{-1}$, with moisture correction to $13 \%$.

The oil content on soybean seeds was carried on a Bruker Minispec mq-20 low-field Nuclear Magnetic Resonance (TD-NMR) spectrometer, equipped with a $0.47 \mathrm{~T}$ permanent magnet (observing the $1 \mathrm{H}$ nucleus at $19.95 \mathrm{MHz}$ ) and with a single-channel $18-\mathrm{mm}$ diameter probe. The magnet temperature, including probe, was kept constant at $40{ }^{\circ} \mathrm{C}$. For this a calibration curve containing six points with different amounts of soybean oil $(10-35 \% \mathrm{~m} / \mathrm{m})$ was performed covering average soybean oil content described in the literature $(21 \% \mathrm{~m} / \mathrm{m})$. After, about $3.0 \mathrm{~g}$ of each soybean seeds sample was transferred into 18-mm NMR tubes and submitted to TD-NMR analysis and the oil content in the seeds was determined by plotting signal intensity in function of the calibration curve. The measurements were performed in triplicate. The measurement was achieved with aid of the spin-echo pulse sequence that consisted of a $90^{\circ}$ x pulse, followed by a time $\tau$ of $3.5 \mathrm{~ms}$, a $180^{\circ}$ y pulse, other time $\tau$, the acquisition, and a recycle delay of $2 \mathrm{~s}$ and 16 scans.

\subsection{Statistical Analysis of the Data}

After collection of data, was performed the analysis of variance (ANOVA) and the average variables were compared by Tukey test at 5\% probability, using the statistical program SISVAR (Ferreira, 2011) software.

\section{Results and Discussion}

\subsection{Parameters of Rainfall, Maximum and Minimum Temperatures}

Rainfall as well as maximum and minimum temperatures during experiment development were provided by Agronomic Institute of Paraná, in a rain gauge installed near the experimental area (Figure 1). 

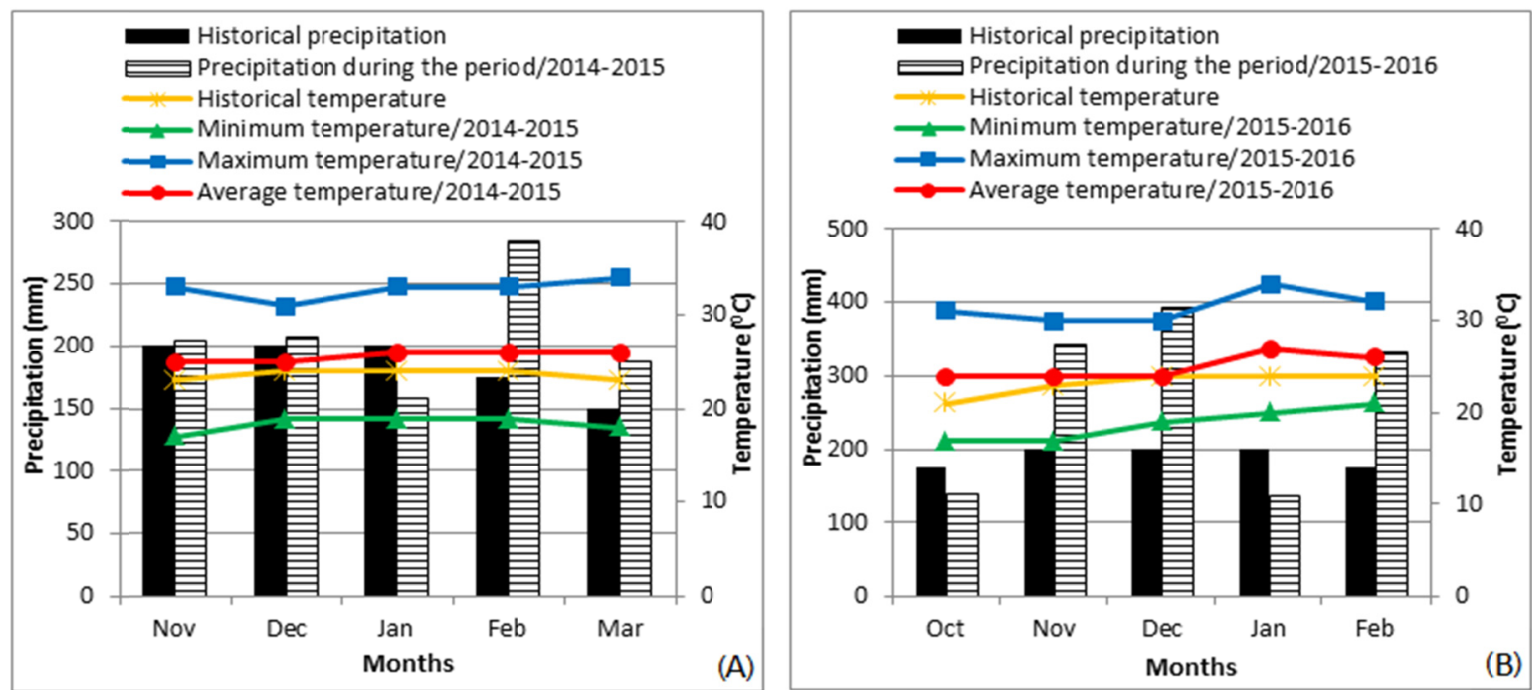

Figure 1. The columns present the historical average monthly precipitation (period of 26 years) and the experimental period and the lines present the minimum, maximum and average temperatures from November/2014 to March/2015 (A) and October/2015 to February/2016 (B), obtained at the Meteorological Station of the Agronomic Institute of Paraná, in Santa Tereza do Oeste-PR

\subsection{Physical Parameters}

The results of soil physical parameters measured for three consecutive years (2014-2016): bulk density, total porosity, microporosity, macroporosity and hydraulic conductivity of saturated soil in treatments with 12 species of vegetation cover and three management systems are shown in Figure 2 (soil layer 0-0.1 m), in Figure 3 (soil layer 0.1-0.2 m) and in Figure 4 (soil layer 0.2-0.3 m). 


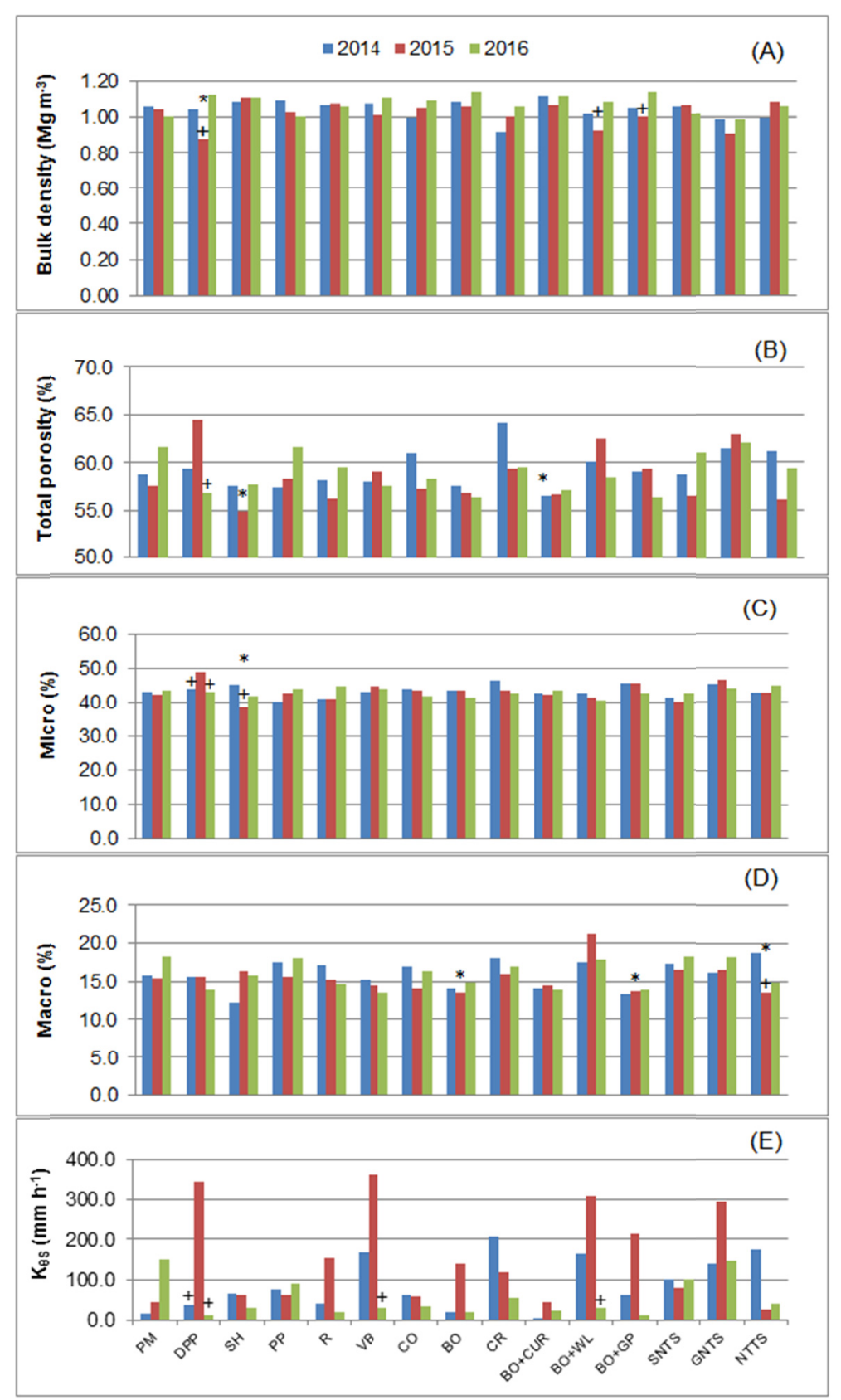

Figure 2. Average values of bulk density (A), total porosity (B), microporosity (C), macroporosity (D) and saturated hydraulic conductivity (E) in treatments with 12 species of vegetation cover and three management systems, in the soil layer of $0-0.1 \mathrm{~m}$

Note. $\mathrm{PM}=$ pearl millet; $\mathrm{DPP}=$ dwarf pigeon pea; $\mathrm{SH}=$ sunn hemp; $\mathrm{PP}=$ pigeon pea $\mathrm{R}=$ rattlebox $; \mathrm{VB}=$ velvet bean; $\mathrm{CO}=$ common oat; $\mathrm{BO}=$ black oat; $\mathrm{CR}=$ cereal rye; $\mathrm{BO}+\mathrm{CUR}=$ black oat + cultivated radish; $\mathrm{BO}+\mathrm{WL}=$ black oat + white lupine; $\mathrm{BO}+\mathrm{GP}=$ black oat + garden pea; SNTS: scarified no-tillage system; GNTS: gypsum no-tillage system; NTTS: no-tillage traditional system (control). When the response variables were influenced between the periods, the mean value was presented and indicated by + and indicated by $*$, when they were influenced between the treatments. 

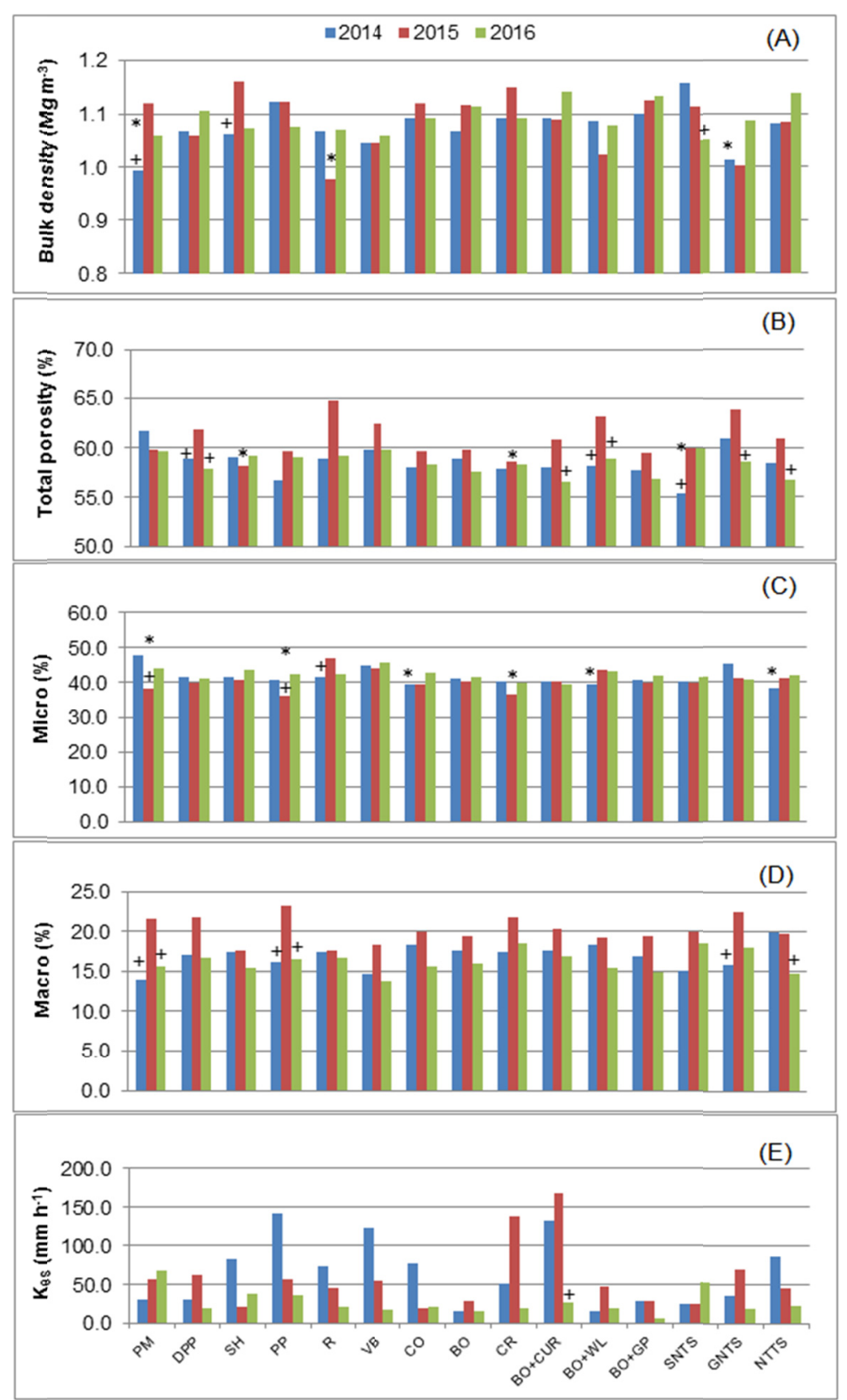

Figure 3. Average values of bulk density (A), total porosity (B), microporosity (C), macroporosity (D) and saturated hydraulic conductivity (E) in treatments with 12 species of vegetation cover and three management systems, in the soil layer of 0.1-0.2 m

Note. $\mathrm{PM}=$ pearl millet; $\mathrm{DPP}=$ dwarf pigeon pea; $\mathrm{SH}=$ sunn hemp; $\mathrm{PP}=$ pigeon pea; $\mathrm{R}=$ rattlebox; $\mathrm{VB}=$ velvet bean; $\mathrm{CO}=$ common oat; $\mathrm{BO}=$ black oat; $\mathrm{CR}=$ cereal rye; $\mathrm{BO}+\mathrm{CUR}=$ black oat + cultivated radish; $\mathrm{BO}+\mathrm{WL}=$ black oat + white lupine; BO+GP = black oat + garden pea; SNTS: scarified no-tillage system; GNTS: gypsum no-tillage system; NTTS: no-tillage traditional system (control). When the response variables were influenced between the periods, the mean value was presented and indicated by + and indicated by $*$, when they were influenced between the treatments. 


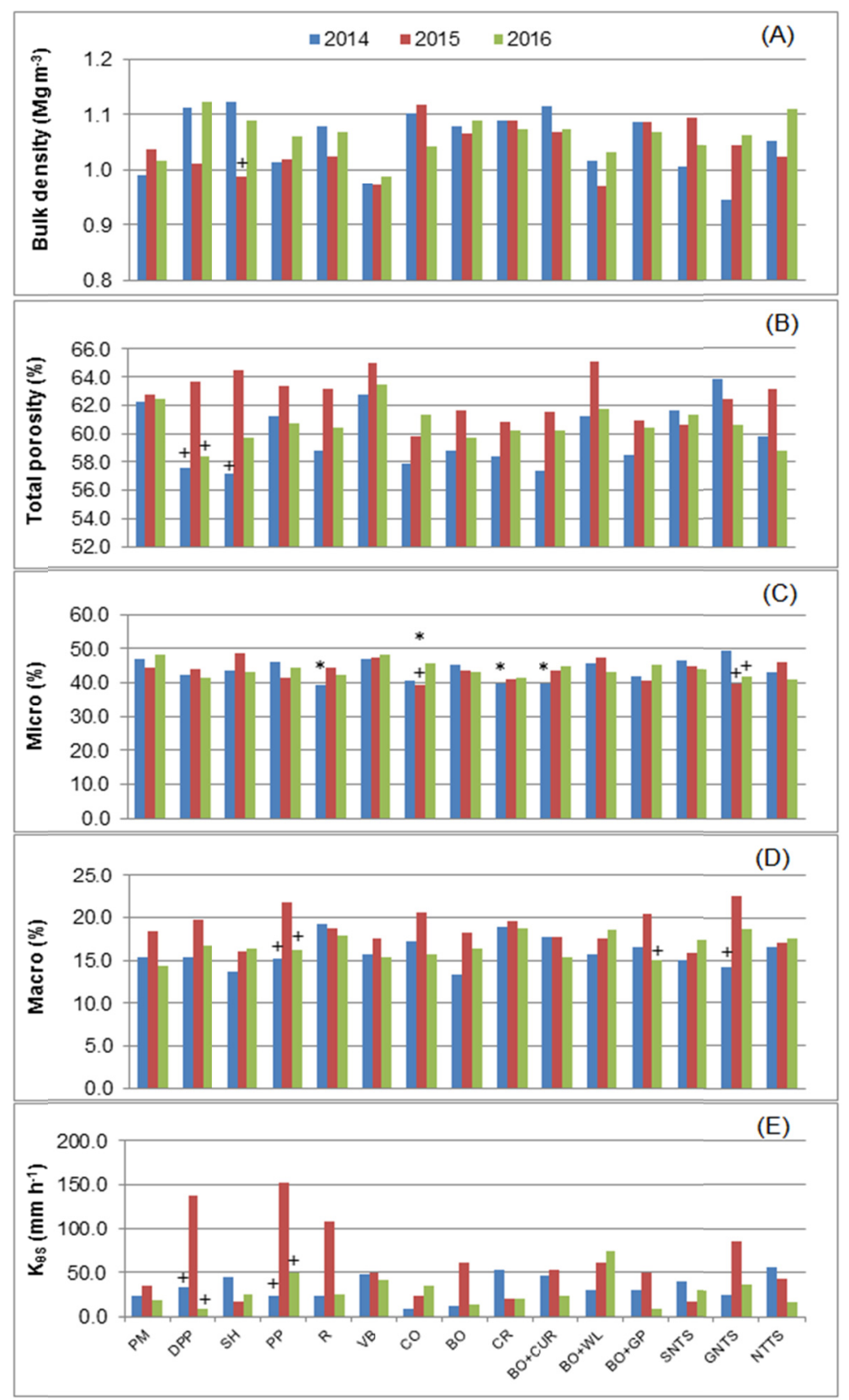

Figure 4. Average values of bulk density (A), total porosity (B), microporosity (C), macroporosity (D) and saturated hydraulic conductivity (E) in treatments with 12 species of vegetation cover and three management systems, in the soil layer of $0.2-0.3 \mathrm{~m}$

Note. $\mathrm{PM}=$ pearl millet; $\mathrm{DPP}=$ dwarf pigeon pea; $\mathrm{SH}=$ sunn hemp; $\mathrm{PP}=$ pigeon pea; $\mathrm{R}=$ rattlebox; $\mathrm{VB}=$ velvet bean; $\mathrm{CO}=$ common oat; $\mathrm{BO}=$ black oat; $\mathrm{CR}=$ cereal rye; $\mathrm{BO}+\mathrm{CUR}=$ black oat + cultivated radish; $\mathrm{BO}+\mathrm{WL}=$ black oat + white lupine; $\mathrm{BO}+\mathrm{GP}=$ black oat + garden pea; SNTS: scarified no-tillage system; GNTS: gypsum no-tillage system; NTTS: no-tillage traditional system (control). When the response variables were influenced between the periods, the mean value was presented and indicated by + and indicated by $*$, when they were influenced between the treatments.

The 0.0-0.1 m layer presented little difference between the treatments and evaluated periods, except for the hydraulic conductivity of saturated soil because it is a physical property that generally presents a high coefficient of variation (Figure 2). In the case the value was $149.26 \%$.

The non-significant differences between the treatments and periods in first layer can be assigned to the mobilization that this layer undergoes to each agricultural crop, by the furrow opening mechanisms of the 
seeder-fertilizer, associated to the fact that it is a layer with high content of organic matter and large volume of biopores generated by the senescence of the roots of the previous cultures.

These observations support those found by Balesdent, Chenu, and Balabane (2000), which report that soil management provides a periodic rupture in the soil structure, changing its the physical properties. Mesquita and Moraes (2004) also state that, due to the soil management in the superficial layers, there is usually a greater variation in bulk density, which may lead to the formation of pores with larger diameters and thus allowing higher hydraulic conductivity of saturated soil values, however, these pores do not always influence bulk density values.

For some authors, the coefficient of variation of hydraulic conductivity of saturated soil is high. It is common for variations of the order of 111.5 and $247.9 \%$, as reported by Lima et al. (2006). Scherpinski et al. (2010) found values of coefficient of variation of $110.24 \%$. Jury et al. (1991) indicated that the coefficient of variation can vary from 48 to $320 \%$. For Warrich and Nielsen (1980) the coefficient of variation can reach values greater than $420 \%$. According to Gurovich (1982), and Lal et al. (1999), this great variability does not because significant differences between treatments, supporting founds in this work.

In the 0.1-0.2 $\mathrm{m}$ layer it was verified that the rattlebox $\left(0.98 \mathrm{Mg} \mathrm{m}^{-3}\right)$ and gypsum no-tillage system $\left(1.00 \mathrm{Mg} \mathrm{m}^{-3}\right)$ treatments provided bulk density values lower than the other treatments, in the year 2015 (Figure 3). For the following year (2016), the bulk density values did not present significant differences between treatments and periods evaluated. The other properties, total porosity, microporosity and macroporosity, did not differ significantly between treatments and periods evaluated, as in the $0-0.1 \mathrm{~m}$ layer (Figure 2). Hydraulic conductivity of saturated soil did not present a significant difference between treatments and evaluated periods, since it is an attribute that generally presents a high coefficient of variation, as already discussed previously.

The non-occurrence of significant differences between treatments and periods evaluated in this layer can be due to the ideals initial structural conditions of the soil of the experimental area, as verified in the data of the year 2014, when it was characterized.

Kiehl (1979) supported that bulk density is considered ideal in the range 1.0 to $1.2 \mathrm{Mg} \mathrm{m}^{-3}$ for clay soils. For the study, these values were lower than the limiting density and still provided increases in total porosity, macroporosity and soil hydraulic conductivity. Another factor that should be emphasized is the macroporosity, which according to Silva and Kato (1997) is an important factor for the hydraulic conductivity of the saturated soil, due to the increase of macroporosity there is an increase in the water infiltration capacity in the soil. Osunbitan, Oyede and Adekalu (2005) also supported that, as the continuity of macroporosity is preserved in the no-tillage system, it contributes to the hydraulic conductivity of the soil.

In general, the 0.2-0.3 m layer did not show a significant effect of the treatments and periods evaluated on the physical attributes of the soil (Figure 4).

The possible explanations may be associated to the good initial structural state and because it is a layer that undergoes lower compression stresses when compared to the superficial layers. In this way, this layer generally suffers smaller deformations and consequently smaller changes in the physical properties.

These founds supports those obtained by Borges et al. (2009) who stated that in deeper layers of the soil, there were no physical-water quality losses in grazing area compared to Brazilian Cerrado natural. Corrêa et al. (2010) also agree that in the $0.2-0.4 \mathrm{~m}$ layer there was no change in physical properties in areas with different types of crops compared to natural vegetation.

Although the management systems have not differed from the soil ground cover species, analyzing only the three management systems as a function of the soil physical attributes, it can be verified that after five months of the soil scarification operation, the values of the density did not differ from those obtained before experiment started. While, 11 months after the application of gypsum, there was a slight improvement in bulk density, total porosity, microporosity, macroporosity and hydraulic conductivity of saturated soil in the 0.0-0.1 and 0.1-0.2 m layers.

\subsection{Soybean Crop}

The results of grain yielding soybean, oil content, 100-grain weight, height of plants and number of plants per meter of soybean crop according to the 12 species of vegetation cover and three predecessor management systems (average of four replications) in the 2015 and 2016 are shown in Figure 5.

Regarding the parameters of the soybean crop, it was observed that the height of plants presented significant interaction among the treatments (Figure 5). 


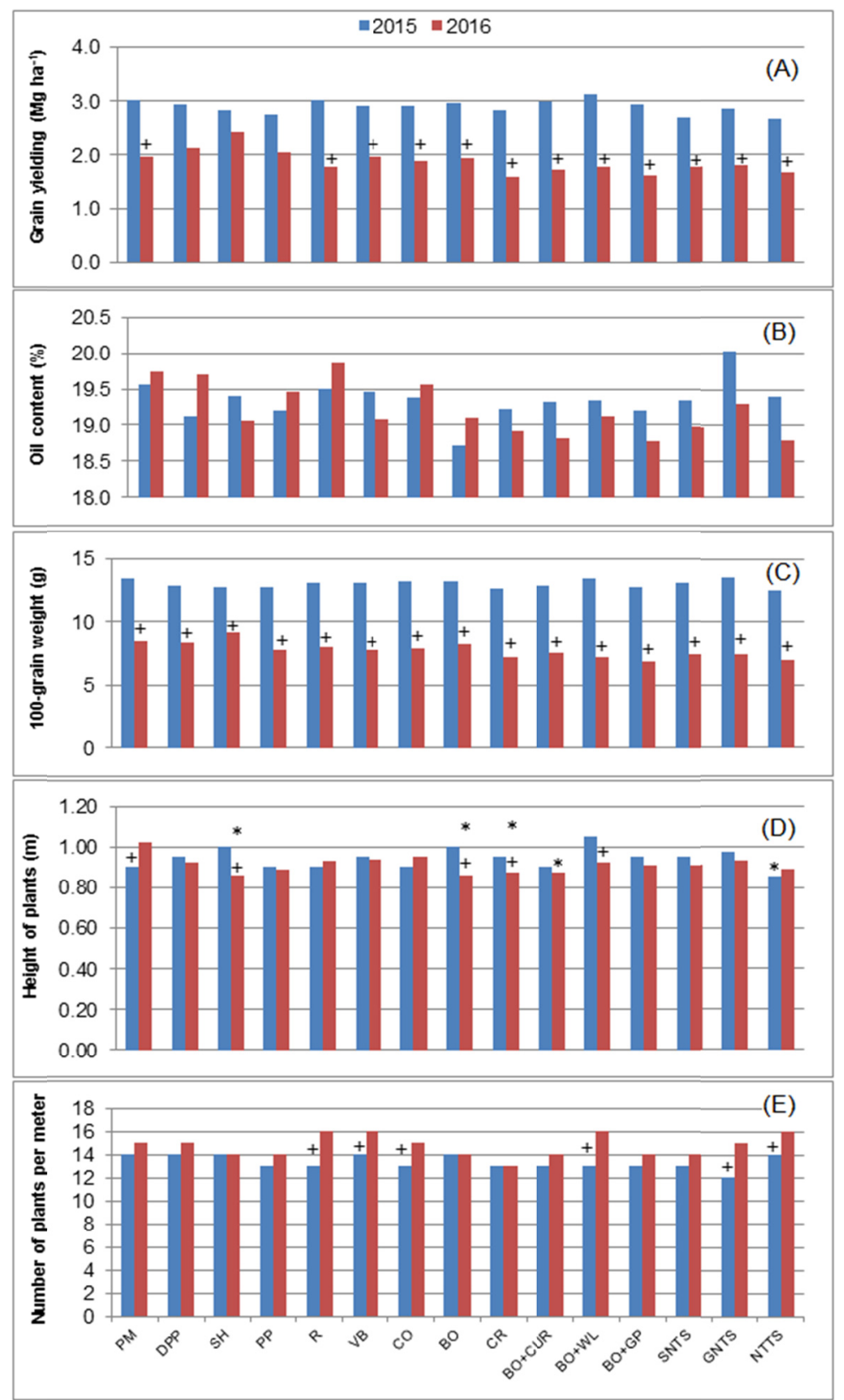

Figure 5. Mean values of grain yielding soybean (A), oil content (B), 100-grain weight (C), height of plants (D) and number of plants per meter (E) of soybean crop according to the 12 species of vegetation cover and three predecessor management systems (average of four replications) in the 2015 and 2016

Note. $\mathrm{PM}=$ pearl millet; $\mathrm{DPP}=$ dwarf pigeon pea; $\mathrm{SH}=$ sunn hemp; $\mathrm{PP}=$ pigeon pea; $\mathrm{R}=$ rattlebox; $\mathrm{VB}=$ velvet bean; $\mathrm{CO}=$ common oat; $\mathrm{BO}=$ black oat; $\mathrm{CR}=$ cereal rye; $\mathrm{BO}+\mathrm{CUR}=$ black oat + cultivated radish; $\mathrm{BO}+\mathrm{WL}=$ black oat + white lupine; $\mathrm{BO}+\mathrm{GP}=$ black oat + garden pea; SNTS: scarified no-tillage system; GNTS: gypsum no-tillage system; NTTS: no-tillage traditional system (control). When the response variables were influenced between the periods, the mean value was presented and indicated by + and indicated by $*$, when they were influenced between the treatments.

It was observed that the height of the soybean plants was greater on the residues of the black oat + white lupine $(1.05 \mathrm{~m})$ cover and the lower heights were observed in the no-tillage traditional system (control) $(0.85 \mathrm{~m})$ plots in the period of 2015. While the highest heights of soybean plants in the period of 2016 occurred on pearl millet residues $(1.02 \mathrm{~m})$ and the lowest heights on sunn hemp and black oat residues with $0.86 \mathrm{~m}$; cereal rye and black oat + cultivated radish with $0.87 \mathrm{~m}$. 
Considering the number of plants, 100-grain weight, yielding and soybean oil content, there were no significant changes were observed according to the evaluated treatments (Figure 5). It was not possible to differentiate the vegetation cover species and management systems that had influence on the soybean crop. Although grain yield did not differ between treatments, the highest yield (3.12 $\mathrm{Mg} \mathrm{ha}^{-1}$, in the period of 2015) was lower than the average of the region that remained at $3.32 \mathrm{Mg} \mathrm{ha}^{-1}$ (Seab, 2015). This difference may be due to the lack of rainfall at the beginning of the vegetative period, in addition to the incidence of Asian soybean rust (Phakopsora pachyrhizi Sidow) in the experimental area.

These founds supports those observed by Sanchez et al. (2014), which verified that winter cover plants (Avena strigosa Schreb), annual ryegrass (Lolium multiflorum Lam.), common vetch (Vicia sativa L.) and cultivated radish (Raphanus sativus L.), did not promote changes in productivity of soybeans in the first crop cycle.

Considering the periods, it was observed that the oil content was the only parameter that did not present significant changes.

The period of 2015 stood out in relation to 2016, presenting the highest values for yield, 100-grain weight and height of plants. On the other hand, the greatest number of plants occurred in the period of 2016.

The severe incidence of Asian soybean rusts harmed seed development, causing low seed weight and negatively impacting grain yield in 2016. The same can be observed also for soybean 100-grain weight that was much lower than the previous year. According to Marques, Rocha and Hamawaki (2008), the 100-grain weight is a variable, which can be used to estimate their efficiency during the grain filling process, in addition to indirectly expressing the size of these seeds and their good physiological condition. Miles et al. (2011) support that Asian soybean rust has been one of the major diseases limiting soybean production.

\section{Conclusion}

Any differences were found in soil scarification after treatments performed demonstrating that the possible beneficial effects persisted for a short time (five months after). On the other hand, eleven months after gypsum application a slight improvement in density, total porosity, microporosity and soil hydraulic conductivity was observed in first layers (0-0.1 and 0.1-0.2 $\mathrm{m}$ deep);

The vegetation cover species that preceded soybean crop as well as soil managements have no effect on grain yielding, oil content, grain weight and number of plants.

\section{Acknowledgements}

This study was funded in part by the Coordination of Improvement of Higher Education Personnel-Brazil (CAPES)-Finance Code 001.

The authors are grateful to CAPES, CNPq, FINEP, Araucária Foundation, UNIOESTE, IAPAR and UFPR for their support in carrying out the research work.

\section{References}

Amaral, A. S., Anghinoni, I., \& Deschamps, F. C. (2004). Resíduos de plantas de cobertura e do calcário aplicado na superfície do solo. Revista Brasileira de Ciência do Solo, 28, 115-123. https://doi.org/10.1590/S0100-068 32004000100012

Balesdent, J., Chenu, C., \& Balabane, M. (2000). Relationship of soil organic matter dynamics to physical protection and tillage. Soil \& Tillage Research, 53, 215-230. https://doi.org/10.1016/S0167-1987(99) 00107-5

Bertin, E. G., Andrioli, I., \& Centurion, J. F. (2005). Plantas de cobertura em pré-safra ao milho em plantio direto. Acta Scientiarum. Agronomy, 27(3), 379-386. https://doi.org/10.4025/actasciagron.v27i3.1393

Bertol, I., Albuquerque, J. A., Leite, D., Amaral, A. J., \& Zoldan Junior, W. A. (2004). Propriedades físicas do solo sob preparo convencional e semeadura direta em rotação e sucessão de culturas, comparada às do campo nativo. Revista Brasileira de Ciência do Solo, 28, 155-163. https://doi.org/10.1590/S0100-06832004000 100015

Borges, T. A., Oliveira, F. A., Silva, E. M. da, \& Goedert, W. J. (2009). Avaliação de parâmetros fisico-hídricos de Latossolo Vermelho sob pastejo e sob cerrado. Revista Brasileira de Engenharia Agrícola e Ambiental, 13(1), 18-25. https://doi.org/10.1590/S1415-43662009000100003

Braida, J. A., Reichert, J. M., Veiga, M da, \& Reinert, D. J. (2006). Resíduos vegetais na superfície e carbono orgânico do solo e suas relações com a densidade máxima obtida no ensaio proctor. Revista Brasileira de Ciência do Solo, 30, 605-614. https://doi.org/10.1590/S0100-06832006000400001 
Bublitz, U. (2014). Evolução do sistema plantio direto no Paraná. Documento elaborado pela EMATER-PR e cedido a FEBRAPDP. Retrieved from http://febrapdp.org.br/download/EVOLUCAO_DO_SPD_NO_ PARANA_2014.pdf

Corrêa, R. M., Freire, M. B. G dos S., Ferreira, R. L. C., Silva, J. A. A. da, Pessoa, L. G. M., Miranda, M. A., \& Melo, D. V. M. de. (2010). Atributos físicos de solos sob diferentes usos com irrigação no semiárido de Pernambuco. Revista Brasileira de Engenharia Agrícola e Ambiental, 14(4), 358-365. https://doi.org/ 10.1590/S1415-43662010000400003

Crusciol, C. A. C., Mateus, G. P., Nascente, A. S., Martins, P. O., Borghi, E., \& Pariz, C. M. (2012). An innovative crop-forage intercrop system: early cycle soybean cultivars and palisade grass. Agronomy Journal, 104(4), 1085-1095. https://doi.org/10.2134/agronj2012.0002

Empresa Brasileira de Pesquisa Agropecuária. (EMBRAPA). (1997). Manual de métodos de análise de solo: Centro Nacional de Pesquisa de Solos (2nd ed.). Rio de Janeiro: Embrapa.

Empresa Brasileira de Pesquisa Agropecuária. (EMBRAPA). (2013). Sistema Brasileiro de Classificação de Solos. Centro Nacional de Pesquisa de Solos (3rd ed.). Rio de Janeiro: Embrapa.

Ferrari Neto, J., Crusciol, C. A. C., Soratto, R. P., \& Costa, C. H. M. da. (2012). Consórcio de guandu-anão com milheto: persistência e liberação de macronutrientes e silício da fitomassa. Bragantia, 71(2), $264-272$. https://doi.org/10.1590/S0006-87052012005000017

Ferreira, D. F. (2011). Sisvar: A computer statistical analysis system. Ciência e Agrotecnologia, 35, $1039-1042$. https://doi.org/10.1590/S1413-70542011000600001

Gabriel Filho, A., Pessoa, A. C. S., Strohhaecker, L., \& Helmich, J. J. (2000). Preparo convencional e cultivo mínimo do solo na cultura de mandioca em condições de adubação verde com ervilhaca e aveia preta. Ciência Rural, 30(6), 953-957. https://doi.org/10.1590/S0103-84782000000600005

Gurovich, L. A. (1982). Field spatial variability structure of soil hydrodynamic properties. Ciência e Investigación Agraria, 9(3), 243-254. https://doi.org/10.7764/rcia.v9i3.560

Hamza, M. A., \& Anderson, W. K. (2005). Soil compaction in cropping systems. A review of the nature, causes and possible solutions. Soil \& Tillage Research, 82, 121-145. https://doi.org/10.1016/j.still.2004.08.009

IAPAR (Instituto Agronômico do Paraná). (2000). Cartas climatológicas do Paraná. In J. H. Caviglione, L. R. B. Kiihl, P. H. Caramori, \& D. Oliveira (Eds.), Cartas climáticas do Paraná. Londrina: IAPAR.

Jury, W. A., Gardner, W. R., \& Gardner, W. H. (1991). Soil physics (5th ed.). John Wiley and Sons: New York.

Kiehl, E. J. (1979). Manual de Edafologia. Piracicaba: Editora Agronômica Ceres.

Lal, R. (1999). Soil compaction and tillage effects on soil physical properties of a Mollic ochraqualf in northwest Ohio. Journal of Sustainable Agriculture, 14(4), 53-65. https://doi.org/10.1300/J064v14n04_06

Lima, C. L. R., Reinert, D. J., Reichert, J. M., Suzuki, L. E. A. S., \& Gubiani, P. I. (2006). Qualidade físico-hídrica e rendimento de soja (Glycine max L.) e feijão (Phaseolus vulgaris L.) de um Argissolo Vermelho distrófico sob diferentes sistemas de manejo. Ciência Rural, 36(4), 1172-1178. https://doi.org/ 10.1590/S0103-84782006000400020

Marques, M. C., Rocha, J. E. da S., \& Hamawaki, O. T. (2008). Avaliação do teor de óleo de cultivares de soja da UFU visando à produção de biodiesel. Horizonte Cientifico, 2(1), 1-22.

Mesquita, M. G. B.F., \& Moraes, S. O. A. (2004). A dependência entre a condutividade hidráulica saturada e atributos físicos do solo. Ciência Rural, 34(3), 963-969. https://doi.org/10.1590/S0103-8478200400030 0052

Miles, M. R., Bonde, M. R., Nester, S. E., Berner, D. K., Frederick, R. D., \& Hartman, G. L. (2011). Characterizing resistance to Phakopsora pachyrhizi in soybean. Plant Disease, 95, 577-581. https://doi.org/ 10.1094/PDIS-06-10-0450

Nascente, A. S., \& Crusciol, C. A. C. (2012). Cover crops and herbicide timing management on soybean yield under no-tillage system. Pesquisa Agropecuária Brasileira, 47(2), 187-192. https://doi.org/10.1590/ S0100-204X2012000200006

Oliveira, P. de, Kluthcouski, J., Favarin, J. L., \& Santos, D. de C. (2011). Consórcio de milho com braquiária e guandu-anão em sistema de dessecação parcial. Pesquisa Agropecuária, 46(10), 1184-1192. https://doi.org/ 10.1590/S0100-204X2011001000010 
Osunbitan, J. A., Oyedele, D. J., \& Adekalu, K. O. (2005). Tillage effects on bulk density, hydraulic conductivity and strength of a loamy sand soil in southwestern Nigeria. Soil \& Tillage Research, 82(1), 57-64. https://doi.org/10.1016/j.still.2004.05.007

Pereira, F. S., Andrioli, I., Beutler, A. N., Almeida, C. X., \& Pereira, F. S. (2010). Physical quality of an oxisol cultivated with maize submitted to cover crops in the pre-cropping period. Revista Brasileira de Ciência do Solo, 34(1), 211-218. https://doi.org/10.1590/S0100-06832010000100021

Reinert, D. J., \& Reichert, J. M. (2006). Coluna de areia para medir a retenção de água no solo-Protótipos e teste. Ciência Rural, 36(6), 1931-1935. https://doi.org/10.1590/S0103-84782006000600044

Sanchez, E., Maggi, M. F., Genú, A. M., \& Müller, M. M. L. (2014). Propriedades físicas do solo e produtividade de soja em sucessão a plantas de cobertura de inverno. Magistra, 26(3), 266-275.

Scherpinski, C., Uribe-Opazo, M. A., Vilas Boas, M. A., Sampaio, S. C., \& Johann, J. A. (2010). Variabilidade espacial da condutividade hidráulica e da infiltração da água no solo. Acta Scientiarum. Agronomy, 32(1), 7-13. https://doi.org/10.4025/actasciagron.v32i1.959

Secco, D., Reinert, D. J., Reichert, J. M., \& Ross, C. O. (2004). Produtividade de soja e propriedades físicas de um latossolo submetido a sistemas de manejo e compactação. Revista Brasileira de Ciência do Solo, 28, 797-804. https://doi.org/10.1590/S0100-06832004000500001

Secretaria da Agricultura e do Abastecimento (SEAB). (2015). Boletins informativos de 2015. Soja - Informe mensal de 25 de junho de 2015. Retrieved from http://www.agricultura.pr.gov.br/modules/qas/aviso.php? codigo $=4420$

Servadio P., Bergonzoli S., \& Toderi M., (2014). Soil mapping to assess workability in central Italy as climate change adaptation techniques. Global Nest Journal, 16(2), 229-239. https://doi.org/10.30955/gnj.001299

Servadio, P. (2010). Applications of empirical methods in central Italy for predicting field wheeled and tracked vehicle performance. Soil Tillage Research, 110(2), 236-242. https://doi.org/10.1016/j.still.2010.08.009

Servadio, P., Bergonzoli, S., \& Beni, C. (2016). Soil tillage systems and wheat yield under climate change scenarios. Agronomy, 6(3), 1-11. https://doi.org/10.3390/agronomy6030043

Silva, C. L. da, \& Kato, E. (1997). Efeito do selamento superficial na condutividade hidráulica saturada da superfície de um solo sob cerrado. Pesquisa Agropecuária Brasileira, 32(2), 213-220.

Silva, V. R., Reinert, D. J., \& Reichert, J. M. (2000). Resistencia mecânica do solo à penetração influenciada pelo tráfego de uma colhedora em dois sistemas de manejo do solo. Ciência Rural, 30(5), $795-801$. https://doi.org/10.1590/S0103-84782000000500009

Silva, V. R., Reinert, D. J., \& Reichert, J. M. (2002). Fatores controladores da compressibilidade de um Argissolo Vermelho-Amarelo distrófico arênico e de um Latossolo Vermelho distrófico típico. II-Grau de saturação em água. Revista Brasileira de Ciência do Solo, 26(1), 9-16. https://doi.org/10.1590/S0100-06832 002000100002

Tormena, C. A., Barbosa, M. C., Costa, A. C. S., \& Gonçalves, A. C. A. (2002). Densidade, porosidade e resistência a penetração em Latossolo cultivado sob diferentes sistemas de preparo do solo. Scientia Agricola, 59(4), 795-801. https://doi.org/10.1590/S0103-90162002000400026

Torres, J. L. R., Pereira, M. G., \& Fabian, A. J. (2013). Coberturas vegetais e atributos físicos do solo sob semeadura direta no cerrado. Retrieved from http://www.iftm.edu.br/proreitorias/pesquisa/revista/pdf/ Resumo_07.pdf

Warrick, A., \& Nielsen, D. R. (1980). Spatial variability of soil physical properties in the field. In D. Hillel (Ed.), Applications of soil physics. New York: Academic. https://doi.org/10.1016/B978-0-12-348580-9.50018-3

\section{Copyrights}

Copyright for this article is retained by the author(s), with first publication rights granted to the journal.

This is an open-access article distributed under the terms and conditions of the Creative Commons Attribution license (http://creativecommons.org/licenses/by/4.0/). 